\title{
Antibiotic therapy for snakebite envenoming
}

Dabor Resiere ${ }^{1, *} \mathbb{D}$, José María Gutiérrez ${ }^{2}$, Rémi Névière ${ }^{1}$, André Cabié3 ${ }^{3}$ Mehdaoui Hossein ${ }^{1}$, Hatem Kallel ${ }^{4}$

${ }^{1}$ Intensive Care Unit, University Hospital of Martinique, Fort-de-France, Martinique.

${ }^{2}$ Instituto Clodomiro Picado, Facultad de Microbiología, Universidad de Costa Rica, San José, Costa Rica.

${ }^{3}$ Department of Infectious Diseases, University Hospital of Martinique, Fort-de-France, Martinique.

${ }^{4}$ Intensive Care Unit, Cayenne General Hospital, Cayenne, French Guiana.

\begin{abstract}
There are numerous conflicting recommendations available on the use of antibiotics following snakebite. The present letter to the editor presents some recommendations based on recent studies, and aims to stimulate debate on this topic.
\end{abstract}

Dear Editor,

According to international guidelines amoxicillin-clavulanate is recommended to prevent secondary infections from animal bites [1]. However, the systematic antibiotic administration after snakebite is questionable. Most authors recommend antibiotics for severely bitten patients or when inflammatory signs are suggestive of infection. Interestingly, empiric amoxicillin-clavulanate use was shown to be ineffective in preventing secondary infections after snakebites, because of the resistance to $\beta$-lactam antibiotics in the bacterial species commonly found infecting snakebite site [2]. Recently, analysis of the antibiotic susceptibility of bacteria isolated from Bothrops lanceolatus mouth showed $67 \%$ of strains resistant to amoxicillin-clavulanate, whereas the majority of isolated bacteria were susceptible to third-generation cephalosporins [3].

* Correspondence: dabor.resiere@chu-martinique.fr http://dx.doi.org/10.1590/1678-9199-JVATITD-2019-0098

Received: 06 December 2019; Accepted: 12 December 2019; Published online: 03 February 2020. 
Wound infection following snakebite usually accounts for 9 to $77 \%$ of the bitten patients, as described in several studies [2, 4-8]. The large differences in the reported prevalence of secondary infections in snakebites can be related to variations in the criteria used to establish the presence of infection. Indeed, there is no precise set of clinical criteria to define infection in snakebite envenomings. In addition, a high proportion of microbiological cultures are negative because of systematic preemptive use of antibiotics in snake bitten patients. The main involved bacteria are Enterococcus faecalis, Aeromonas hydrophila and Morganella morganii [2, 4-9].

The snake mouth is colonized by bacteria that can be transmitted to the bitten patient through the skin injury associated with the bite [3, 10-12]. Inoculation of bacteria from the mouth, fangs, or venom following snakebite can cause local infection with abscess and necrotizing fasciitis in most severe cases [13]. In one recent study, isolated Enterobacteriaceae following snake bite infection showed $69 \%$ resistance to ampicillin, $60 \%$ resistance to amoxicillin/clavulanate, and $66 \%$ resistance to second-generation cephalosporins [13]. Conformingly, our experimental study examining the bacteria sampled from the oral cavity of $26 \mathrm{~B}$. lanceolatus specimens collected from various areas in Martinique supported that $67 \%$ of the isolated bacteria were resistant to amoxicillin/clavulanate. In addition, the majority of isolated bacteria were susceptible to third-generation cephalosporins (i.e., $73 \%$ to cefotaxime and $80 \%$ to ceftazidime) [3]. Based on the most frequently isolated bacteria and susceptibility profiles documented in cases of infection after snakebite, active antibiotics include third generation cephalosporins, piperacillintazobactam and ciprofloxacin.

In conclusion, preemptive antibiotic administration in snakebitten patients should be considered only in those with severe local signs of envenomation, and empiric one in those having local or general signs of infection, regardless of the degree of envenoming. The most appropriate empirical antibiotics are third generation cephalosporins. Empirical amoxicillin-clavulanate should no longer be used in this context.

\section{Availability of data and materials}

Not applicable.

\section{Funding}

Not applicable.

\section{Competing interests}

The authors declare that they have no competing interests.

\section{Authors' contributions}

DR, JMG, RN, AC, MH, and HK participated in the conceptual preparation of the paper, the writing and editing of the manuscript, and agreed with its final content.

\section{Ethics approval}

Not applicable.

\section{Consent for publication}

Not applicable.

\section{References}

1. Stevens DL, Bisno AL, Chambers HF, Dellinger EP, Goldstein EJC, Gorbach $\mathrm{SL}$, et al. Practice guidelines for the diagnosis and management of skin and soft tissue infections: 2014 update by the infectious diseases society of America. Clin Infect Dis. 2014;59:147-59.

2. Sachett JAG, da Silva IM, Alves EC, Oliveira SS, Sampaio VS, do Vale FF, et al. Poor efficacy of preemptive amoxicillin clavulanate for preventing secondary infection from Bothrops snakebites in the Brazilian Amazon: A randomized controlled clinical trial. PLoS Negl Trop Dis. 2017;11(7):e0005745.

3. Résière $D$, Olive $C$, Kallel $H$, Cabié $A$, Névière $R$, Mégarbane $B$, et al. Oral microbiota of the snake Bothrops lanceolatus in Martinique. Int J Environ Res Public Health. 2018;15(10):2122.

4. Garg A, Sujatha S, Garg J, Acharya NS, Chandra Parija S. Wound infections secondary to snakebite. J Infect Dev Ctries. 2009;3:221-3.

5. Wagener $M$, Naidoo $M$, Aldous $C$. Wound infection secondary to snakebite. S Afr Med J. 2017;107(4):315-9.

6. Mao Y-C, Liu P-Y, Hung D-Z, Lai W-C, Huang S-T, Hung Y-M, et al. Bacteriology of Naja atra snakebite wound and its implications for antibiotic therapy. Am J Trop Med Hyg. 2016;94:1129-35.

7. Chen C-M, Wu K-G, Chen C-J, Wang C-M. Bacterial infection in association with snakebite: a 10-year experience in a northern Taiwan medical center. J Microbiol Immunol Infect. 2011;44(6):456-60.

8. Hsieh Y-H, Hsueh J-H, Liu W-C, Yang K-C, Hsu K-C, Lin C-T, et al. Contributing factors for complications and outcomes in patients with snakebite: experience in a medical center in southern Taiwan. Ann Plast Surg. 2017;78(3 Suppl 2):S32-S36.

9. Resiere D, Mehdaoui H, Névière R, Olive C, Severyns M, Beaudoin A, et al. Infectious complications following snakebite by Bothrops lanceolatus in Martinique: a case series. Am J Trop Med Hyg. Forthcoming 2019. doi: 10.4269/ajtmh.

10. Barbosa LN, Ferreira Jr RS, Luiza Mello P, Garcia Garces H, Luana Chechi J, Frachin $\mathrm{T}$, et al. Molecular identification and phylogenetic analysis of Bothrops insularis bacterial and fungal microbiota. J Toxicol Environ Health A. 2018;81(6):142-53.

11. Campagner MV, Bosco SMG, Bagagli E, Cunha MLRS, Jeronimo BC, Saad $E$, et al. Microbiological evaluation of different strategies for management of snakes in captivity. J Toxicol Environ Health A. 2012;75(16-17):1070-80.

12. Krishnankutty SP, Muraleedharan M, Perumal RC, Michael S, Benny J, Balan B, et al. Next-generation sequencing analysis reveals high bacterial diversity in wild venomous and non-venomous snakes from India. J Venom Anim Toxins incl Trop Dis. 2018;24:41. doi: 10.1186/s40409-018-0181-8.

13. Lam KK, Crow P, Ng KHL, Shek KC, Fung HT, Ades G, et al. A crosssectional survey of snake oral bacterial flora from Hong Kong, SAR, China. Emerg Med J. 2011;28(2):107-14. 